\title{
DOENÇAS EM CULTIVOS HIDROPÔNICOS DE ALFACE NA REGIÃO METROPOLITANA DE CURITIBA/PR
}

\section{LETTUCE DISEASES IN HYDROPONIC CULTIVATION IN THE METROPOLITAN GREEN BELT OF CURITIBA, PARANÁ STATE, BRAZIL}

\author{
Michele Strapasson Caillet da SILVA ${ }^{1}$ \\ Vismar da Costa LIMA NETO²
}

\begin{abstract}
RESUMO
Em levantamentos realizados entre 2003 e 2004, em dez propriedades produtoras de alface (Lactuca sativa L.) sob cultivo hidropônico, abrangendo cinco municípios da região metropolitana de Curitiba/PR, foram identificadas as seguintes doenças: míldio (Bremia lactucae), oídio (Oidium sp.), queima da saia (Rhizoctonia solani), podridão de esclerotínia (Sclerotinia sclerotiorum), podridão mole (Pectobacterium carotovorum), vírus do mosaico comum da alface (lettuce mosaic vírus) e o complexo do espessamento clorótico das nervuras constituído pelos vírus Mirafiori da alface (Mirafiori lettuce virus) e o vírus associado do espessamento clorótico (Lettuce big vein associated virus). Míldio, mosaico da alface, o complexo do espessamento clorótico, queima da saia e podridão de esclerotínia foram mais prevalentes nos meses mais frescos do ano. Oídio e podridão mole foram de ocorrência mais comum nos meses mais quentes.
\end{abstract}

Palavras-chave: doenças fúngicas; doenças bacterianas; doenças viróticas; doenças da alface; hidroponia; Lactuca sativa.

\begin{abstract}
During surveys carried out in 2003 and 2004, covering ten lettuce (Lactuca sativa L.) growing properties in five municipalities of the green belt of Curitiba, the following diseases were identified: downy mildew (Bremia lactucae), powdery mildew (Oidium sp.) rhizoctoniosis (Rhizoctonia solani), sclerotiniosis (Sclerotinia sclerotiorum) bacterial soft rot (Pectobacterium carotovorum), and Lettuce mosaic virus. Also, the lettuce big vein-associated and Mirafiori lettuce virus, responsible by the lettuce big vein syndrome. The diseases were found in fields of all five municipalities. Downy mildew, Lettuce mosaic virus, big vein viral complex, rhizoctoniosis and sclerotiniosis were prevalent in colder months, while powdery mildew and bacterial soft rot prevailed in hotter months.

Key-words: bacterial diseases; fungal diseases; lettuce diseases; hydropony; Lactuca sativa; virus diseases.
\end{abstract}

\footnotetext{
1 Engenheira Agrônoma, Mestre em Ciências. E mail: mistrapasson@yahoo.com.br

${ }^{2}$ Engenheiro Agrônomo, Doutor em Agronomia, Professor do Departamento de Fitotecnia e Fitossanitarismo da UFPR, Rua dos Funcionários 1540, 80035-050, Curitiba-PR. vismar@ufpr.br. Autor para correspondência
} 
SILVA, M.S.C. e LIMA NETO, V.C. Doenças em cultivos hidropônicos...

\section{INTRODUÇÃO}

O cultivo hidropônico de olerícolas tem se difundido rapidamente em todo o País, especialmente nas regiões sul e sudeste. Tal velocidade de expansão pode ser atribuída a uma série de fatores: melhor preço final do produto, demanda por produtos de qualidade superior e maior difusão de tecnologia. Dentre as hortaliças cultivadas a alface (Lactuca sativa L.) destaca-se entre as folhosas.

O cultivo protegido, dentre eles a hidroponia, possibilitou alterar, de modo acentuado, o ambiente de crescimento e de reprodução de plantas, com o controle parcial dos efeitos adversos de clima permitindo obter colheitas fora de época normal, maior crescimento das plantas, precocidade, aumento do período de colheita e melhora na qualidade de produção (ARAÚJO, 1991; SANTOS, 1994).

Embora tenha ocorrido rápida expansão no Brasil não existem, ainda, dados precisos e atualizados sobre a área cultivada. As informações técnicas sobre o desempenho das plantas em ambiente protegido são insuficientes. Praticamente, não há nada publicado em relação a doenças em cultivos hidropônicos, notadamente a alface. Exceto por algumas pesquisas pontuais publicadas, a bibliografia disponível atualmente, na maioria das vezes, é constituída de monografias baseadas em dados obtidos de literatura estrangeira.

VIDA et al. (2001) ressaltam que pesquisas que possam dar suporte às recomendações e contribuir para maior expansão e tecnificação dessa atividade são necessárias. Esses fatores, associados à escassez de fundamento epidemiológico, têm dificultado o manejo das doenças nesse sistema, uma vez que o sucesso no controle requer a identificação correta dos agentes causais e conhecimento detalhado do seu ciclo de vida, do seu comportamento na planta e dos efeitos dos fatores do ambiente na interação com o hospedeiro. Apesar da importância crescente do cultivo hidropônico na agricultura sustentável existem poucos trabalhos relacionados à diagnose e epidemiologia de doenças, ficando os mesmos restritos a ocorrência e controle (GOMES e RODRIGUES,2001).

A execução de pesquisas em nível regional em hidroponia, dada as particularidades de condições climáticas e utilização de técnicas diferenciadas adotadas por produtores, é um fator importante para a adoção de medidas de manejo de doenças eficientes. O crescimento de plantas em solução nutritiva adiciona uma nova e significativa variável em relação à disseminação de patógenos. A despeito de que possam ser os mesmos agentes causais que ocorrem nos sistemas orgânico e convencional, há probabilidade que adquiram importância maior no cultivo hidropônico, principalmente aqueles que se disseminam rapidamente em meio líquido, no caso, a solução nutritiva, devendo, portanto, ser manejados de maneira diferenciada.

Este trabalho teve por objetivo identificar os agentes etiológicos das doenças predominantes em alface, sob cultivo hidropônico, em municípios produtores da região metropolitana de Curitiba-PR.

\section{METODOLOGIA}

O levantamento foi realizado no período compreendido entre $01^{\circ}$ semestre de 2003 ao $2^{\circ}$ semestre de 2004, em dez propriedades de produção comercial de alface hidropônica, situadas nos municípios de Colombo, Campina Grande do Sul, Campo Magro, Araucária e Curitiba. Foi realizado o acompanhamento dos ciclos produtivos da cultura e dos tratos culturais. As plantas suspeitas de infecção por fungos, bactérias e vírus foram coletadas em todas as fases de produção (formação de mudassementeira, pré-crescimento, crescimento final e colheita) para fins de diagnose. As amostras foram acondicionadas em sacos plásticos identificados com o nome da propriedade, nome da variedade, data da coleta e fase de desenvolvimento da planta de acordo com as técnicas descritas por LIMA NETO et al. (2003).

Em todas as propriedades inspecionadas é adotado o sistema NFT (nutrient film technique) ou técnica do fluxo laminar de nutrientes, onde a solução nutritiva é bombeada aos perfis hidropônicos (tubos de polipropileno) contendo furos, no espaçamento recomendado, para a colocação das mudas de alface. Esse conjunto constitui as bancadas de cultivo onde a solução escoa por gravidade, formando uma fina lâmina que irriga as raízes, retornando ao reservatório. As mudas de alface são produzidas, nas propriedades ou adquiridas de produtores especializados, a partir de sementes germinadas em bandejas de isopor contendo substrato o qual, na ocasião do transplante para os perfis de cultivo, permanece aderido às raízes.

Os procedimentos para a identificação dos agentes causais (testes de patogenicidade, microscopia de luz, microscopia eletrônica de transmissão e ELISA) foram realizados nos laboratórios da Universidade Federal do Paraná, do Centro de Diagnóstico Marcos Enrietti (SEAB/DEFIS) e do Instituto Biológico, São Paulo/SP. Em todos os testes realizados foram utilizadas as variedades de alface Verônica, Vera (crespas) e Elisa (lisa).

No procedimento padrão para as inoculações mecânicas, as folhas retiradas de plantas com suspeita de infecção por vírus foram maceradas em almofariz de porcelana na presença de solução buffer a $0,02 \mathrm{~mol} \mathrm{~L}^{-1}$ composta de $250 \mathrm{ml}$ de água destilada esterilizada, $10 \mathrm{ml}$ de fosfato de potássio, $15 \mathrm{ml}$ de fosfato dissódico e $0,6 \mathrm{~g}$ de sulfito de sódio. A inoculação foi procedida com o auxílio de carborundum 300 mesh em plantas de alface sadias com 20 dias de idade. Posteriormente, a folhas foram lavadas com água para retirar o excesso de carborundum e solução buffer e as plantas mantidas em casa de vegetação. Nos casos de transmissão positiva, folhas dessas plantas-teste foram enviadas para o laboratório de Microscopia Eletrônica Vegetal 
SILVA, M.S.C. e LIMA NETO, V.C. Doenças em cultivos hidropônicos...

(Instituto Biológico/SP) para serem procedidas observações em microscópio eletrônico de transmissão. No laboratório de Fitovirologia e Fisiopatologia do Instituto Biológico/SP, foram realizados, a partir dessas amostras, testes serológicos pelo método DAS-Enzyme linked immunosorbent assay (ELISA), com antissoro específico para Mirafiori Lettuce Vírus (MilLV) e Lettuce Big-Vein Associated Virus(LBVAV). Os procedimentos para a identificação das doenças fúngicas e bacterianas foram realizados de acordo com metodologia descrita pelos autores nas referências citadas na Tabela 1.

TABELA 1 - Metodologia utilizada na Identificação das doenças da alface em cultivos hidropônicos na região metropolitana de Curitiba/ PR. 2004.

\begin{tabular}{|c|c|c|c|c|}
\hline Amostra & Isolamento & Repicagem & Teste de patogenicidade & Identificação \\
\hline $\begin{array}{l}\text { Folhas com } \\
\text { sintomas de } \\
\text { oídio e míldio }\end{array}$ & - & - & $\begin{array}{c}\text { Pulverização de plantas jovens sadias } \\
\text { com suspensões de conídios retirados } \\
\text { de plantas com sintomas, permanência } \\
\text { em câmara úmida, conforme } \\
\text { metodologia preconizada por } \\
\text { KAMIKOGA (2001) para oídio e } \\
\text { ALMADA (1998) para míldio. }\end{array}$ & \multirow{3}{*}{$\begin{array}{l}\text { Registro do } \\
\text { desenvolvimento de } \\
\text { sintomas e sinais, } \\
\text { direta por } \\
\text { microscopia de luz, } \\
\text { utilização de chave } \\
\text { taxonômica e } \\
\text { bibliografia } \\
\text { MORGAN,1981; } \\
\text { MORDUE, 1974; } \\
\text { MORDUE e } \\
\text { HOLLIDAY, } 1976 \text {. }\end{array}$} \\
\hline \multirow[t]{2}{*}{$\begin{array}{l}\text { Raízes e colo } \\
\text { de plantas com } \\
\text { sintomas de } \\
\text { rizotoniose e } \\
\text { esclerotiniose }\end{array}$} & \multirow{2}{*}{$\begin{array}{l}\text { A partir de lesões, } \\
\text { fragmentadas }(3 \mathrm{~mm}) \\
\text { da região limítrofe } \\
\text { entre o tecido doente } \\
\text { e o tecido sadio. } \\
\text { Desinfecção com } \\
\text { hipoclorito de sódio } \\
0,5 \% \text {, por } 2 \text { a } 3 \text { min. } \\
\text { Transferência para } \\
\text { placas de Petri } \\
\text { contendo meio AA, } \\
\text { incubação em estufa } \\
\text { por } 3 \text { dias a } 22^{\circ} \mathrm{C} \text {. }\end{array}$} & \multirow{2}{*}{$\begin{array}{c}\text { A partir de } \\
\text { fragmentos de } \\
\text { estrutura fúngica } \\
\text { em meio de cultura } \\
\text { transferidos } \\
\text { assepticamente } \\
\text { para placas de } \\
\text { Petri contendo } \mathrm{BDA} \\
\text { e incubação em } \\
\text { estufa a } 22^{\circ} \mathrm{C} \text {, por } \\
7 \text { a } 10 \text { dias }\end{array}$} & $\begin{array}{c}\text { Para rizotoniose: Inoculação em } \\
\text { plantas com } 20 \text { dias de idade, } \\
\text { transplantadas em vasos contendo solo } \\
\text { estéril. Discos do meio de cultura } \\
\text { contendo micélio colocado em contato } \\
\text { com o colo das plantas (com e sem } \\
\text { ferimento com estilete). Após a } \\
\text { inoculação, foi colocado sobre o disco, } \\
\text { algodão embebido em água destilada } \\
\text { esterilizada, permanência em câmara } \\
\text { úmida }\end{array}$ & \\
\hline & & & $\begin{array}{l}\text { Para esclerotiniose: Inoculação em } \\
\text { plantas com } 20 \text { dias de idade, } \\
\text { transplantadas em vasos contendo solo } \\
\text { estéril, com macerado contendo água } \\
\text { destilada e estruturas fúngicas } \\
\text { retiradas do meio de cultura. } \\
\text { Pulverização no colo da planta. }\end{array}$ & \\
\hline $\begin{array}{l}\text { Raízes e Colo } \\
\text { de plantas com } \\
\text { sintomas de } \\
\text { podridão mole }\end{array}$ & $\begin{array}{l}\text { Indireto, a partir de } \\
\text { frutos de pimentão, } \\
\text { conforme } \\
\text { metodologia de } \\
\text { TAKATSU et al. } \\
\text { (1981) }\end{array}$ & $\begin{array}{l}\text { Para meio nutriente } \\
\text { Agar, incubação } \\
\text { em estufa por } 6 \\
\text { dias. }\end{array}$ & $\begin{array}{l}\text { Inoculação no colo da planta - } \\
\text { ferimento com estilete - conforme } \\
\text { metodologia de ROMEIRO (1998). }\end{array}$ & $\begin{array}{l}\text { Testes bioquímicos, } \\
\text { tintoriais e biológicos } \\
\text { (SCHAAD, 1980) }\end{array}$ \\
\hline $\begin{array}{c}\text { Folhas com } \\
\text { sintomas de } \\
\text { espessamento } \\
\text { de nervuras e } \\
\text { mosaico }\end{array}$ & - & - & $\begin{array}{l}\text { Inoculações mecânicas a partir de } \\
\text { macerados de folhas de plantas com } \\
\text { sintomas em plantas teste sadias. }\end{array}$ & $\begin{array}{c}\text { Registro do } \\
\text { desenvolvimento de } \\
\text { sintomas. Teste } \\
\text { ELISA com } \\
\text { antissoros } \\
\text { específicos, } \\
\text { observações em } \\
\text { microscópio } \\
\text { eletrônico de } \\
\text { transmissão } \\
\text { (ROGGERO et al. } \\
\text { 2000;TOMLINSON, } \\
\text { 1970). }\end{array}$ \\
\hline
\end{tabular}


SILVA, M.S.C. e LIMA NETO, V.C. Doenças em cultivos hidropônicos...

\section{RESULTADOS E DISCUSSÃO}

Foram identificadas sete doenças na cultura da alface, sendo quatro de natureza fúngica, duas viróticas e uma bacteriana (Tabela 2).

O levantamento realizado mostrou que as doenças identificadas ocorreram nas dez propriedades inspecionadas durante o ano todo e em todas as variedades de alface cultivadas pelos produtores
(Elisa, Isabele, Lídia, Roxane, Vera e Verônica). Em relação à porcentagem de incidência o míldio, o mosaico da alface, o complexo do espessamento clorótico, podridão de esclerotínia e queima da saia foram mais prevalentes nos meses mais frescos do ano (outono e inverno). Oídio e podridão mole foram prevalentes nos meses de primavera e verão.

TABELA 2 - Doenças identificadas em cultivos de alface hidropônica na região metropolitana de Curitiba. Curitiba 2003/2004.

\begin{tabular}{|c|c|c|c|c|}
\hline $\begin{array}{l}\text { NOME COMUM DA } \\
\text { DOENÇA }\end{array}$ & AGENTE CAUSAL & $\begin{array}{l}\text { PROPRIEDADES } \\
\text { INSPECIONADAS/ } \\
\text { OCORRENCIA } \\
\end{array}$ & $\begin{array}{c}\text { OCORRÊNCIA/ } \\
\text { ÉPOCA DO } \\
\text { ANO }\end{array}$ & $\begin{array}{l}\text { VARIEDADES } \\
\text { CULTIVADAS }\end{array}$ \\
\hline $\begin{array}{l}\text { Queima da saia, } \\
\text { rizotoniose. }\end{array}$ & Rhizoctonia solani Kuhn. & $10 / 10$ & $\begin{array}{l}\text { Ano todo. Maior } \\
\text { ocorrência: } \\
\text { primavera/ } \\
\text { outono/inverno }\end{array}$ & \multirow{6}{*}{$\begin{array}{l}\text { Elisa } \\
\text { Isabele } \\
\text { Lídia } \\
\text { Roxane } \\
\text { Vera } \\
\text { Verônica }\end{array}$} \\
\hline Oídio. & $\begin{array}{l}\text { Oidium sp., forma anamórfica de } \\
\text { Erysiphe cichoracearum DC. }\end{array}$ & $10 / 10$ & $\begin{array}{l}\text { Ano todo. Maior } \\
\text { ocorrência na } \\
\text { primavera, } \\
\text { verão. }\end{array}$ & \\
\hline Míldio. & Bremia lactucae Regel. & $10 / 10$ & $\begin{array}{l}\text { Ano todo. Maior } \\
\text { ocorrência no } \\
\text { primavera/ } \\
\text { outono e início } \\
\text { inverno. }\end{array}$ & \\
\hline $\begin{array}{lr}\text { Podridão } & \text { de } \\
\text { esclerotínia, mofo } \\
\text { branco, }\end{array}$ & $\begin{array}{l}\text { Sclerotinia sclerotiorum (Lib.) De } \\
\text { Bary. }\end{array}$ & $10 / 10$ & $\begin{array}{l}\text { Maior } \\
\text { ocorrência: } \\
\text { primavera/ } \\
\text { outono/inverno. }\end{array}$ & \\
\hline $\begin{array}{l}\text { Podridão mole, } \\
\text { podridão } \\
\text { bacteriana. }\end{array}$ & $\begin{array}{l}\text { Pectobacterium carotovorum } \\
\text { (Jones) Waldee=Erwinia } \\
\text { carotovora pv. carotovora. }\end{array}$ & $10 / 10$ & $\begin{array}{l}\text { Maior } \\
\text { ocorrência: } \\
\text { primavera e } \\
\text { verão. }\end{array}$ & \\
\hline $\begin{array}{l}\text { Espessamento } \\
\text { clorótico das } \\
\text { nervuras } \\
\text { (complexo). }\end{array}$ & $\begin{array}{l}\text { Vírus Mirafiori da alface (Mirafiori } \\
\text { lettuce vírus, MiLV, família ainda } \\
\text { não especificada, gênero } \\
\text { Ophiovirus) e vírus associado do } \\
\text { espessamento clorótico (Lettuce } \\
\text { big vein associated virus, LBVAV, } \\
\text { família ainda não especificada, } \\
\text { gênero Varicosavirus). }\end{array}$ & $10 / 10$ & $\begin{array}{l}\text { Maior } \\
\text { ocorrência: } \\
\text { outono e } \\
\text { inverno. }\end{array}$ & \\
\hline
\end{tabular}


SILVA, M.S.C. e LIMA NETO, V.C. Doenças em cultivos hidropônicos...
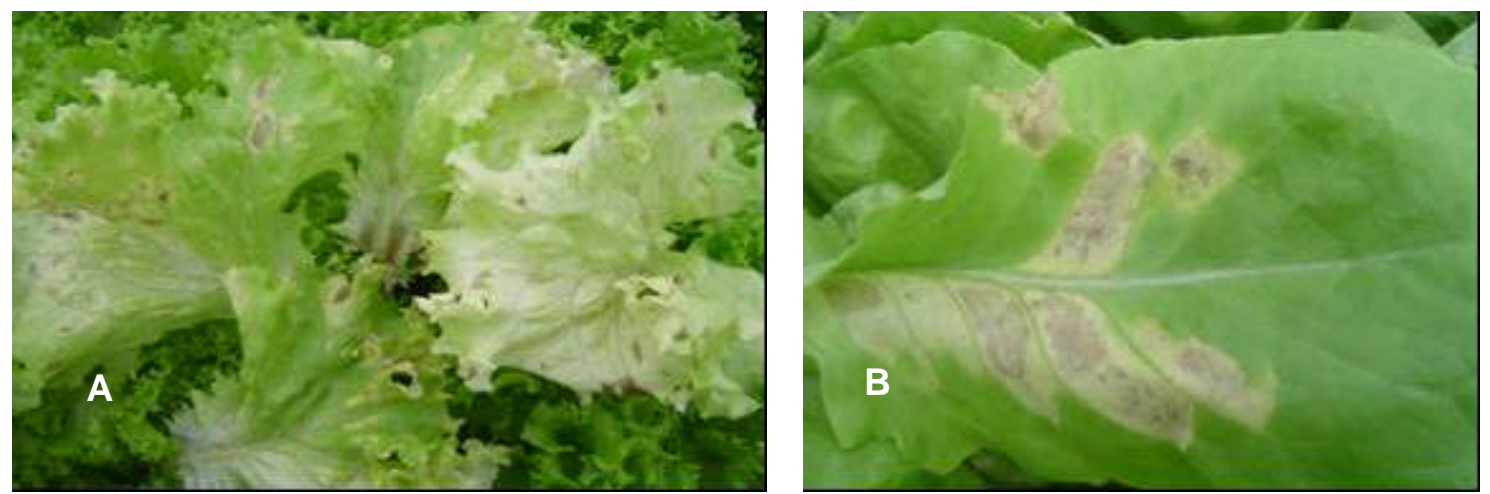

1. MÍLDIO (Bremia lactucae) - (A) Manchas necróticas em plantas infectadas (B) detalhe das lesões em folha
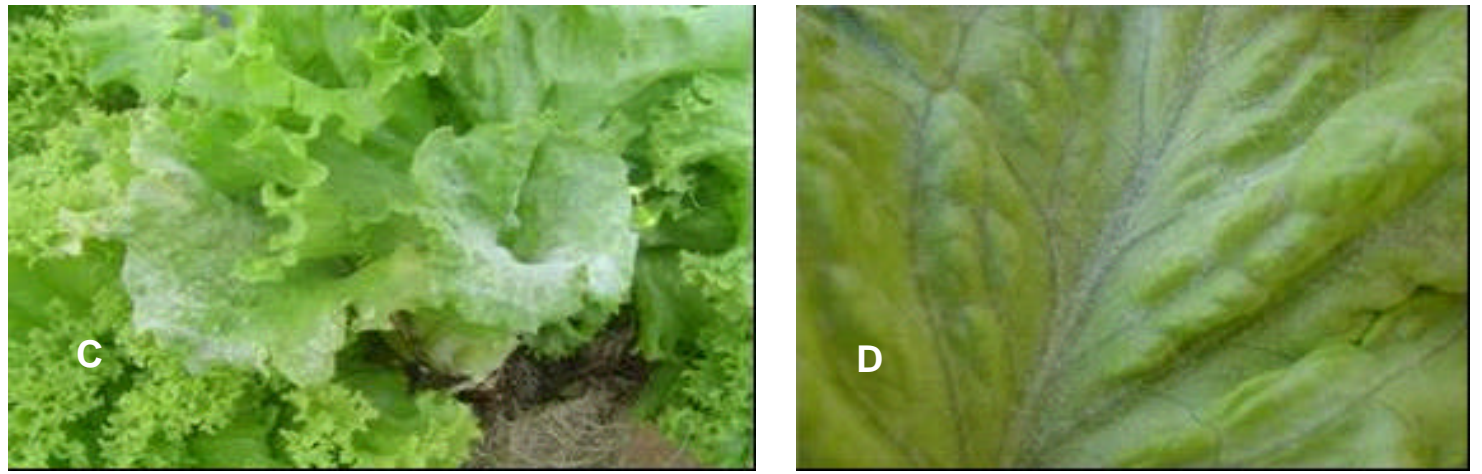

2. OÍDIO (Oidium sp.) - (C) Sintomas em planta adulta (D) detalhe dos sinais (eflorescência) em folha
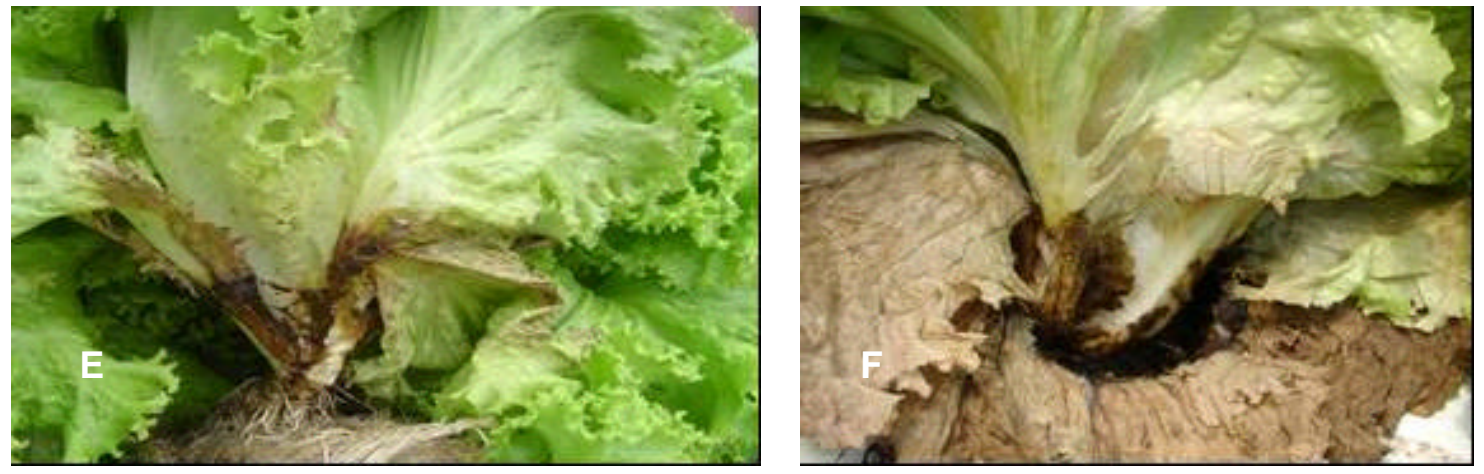

3. QUEIMA DA SAIA (Rhizoctonia solani) - (E) Planta adulta com sintomas (F) detalhe do colo infectado
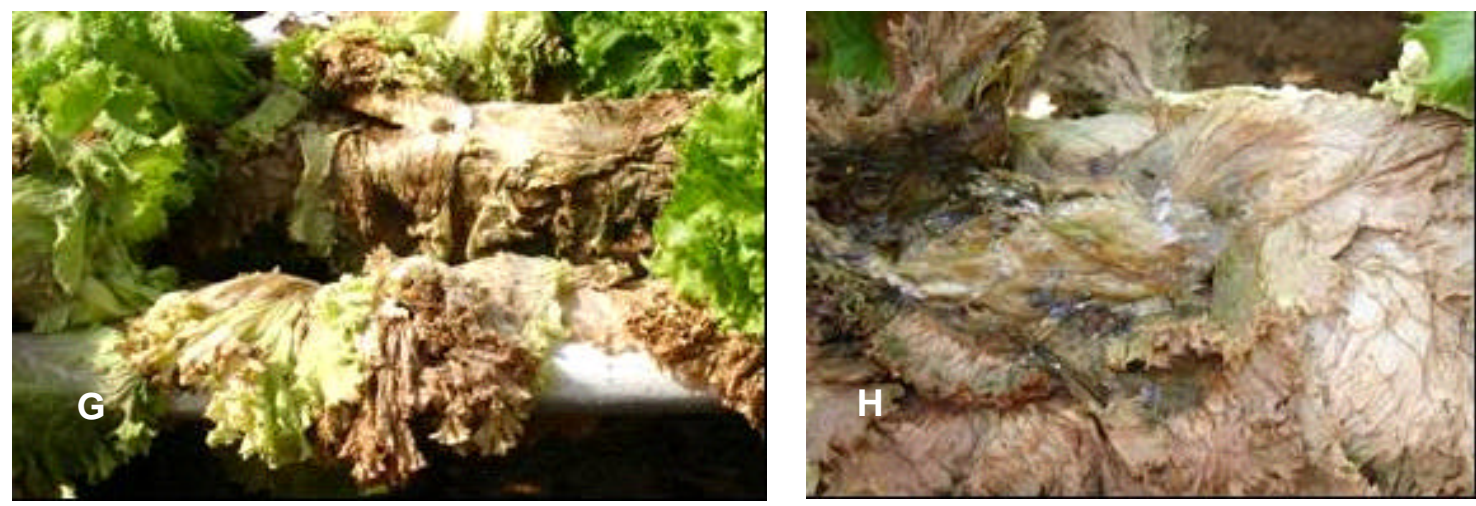

4. ESCLEROTINIOSE (Sclerotinia sclerotiorum) - (G) Sintomas em plantas adultas (H) presença de esclerócios formados sobre as folhas na fase final da doença

FIGURA 1- Sintomas de doenças fúngicas em alface hidropônica 
SILVA, M.S.C. e LIMA NETO, V.C. Doenças em cultivos hidropônicos...
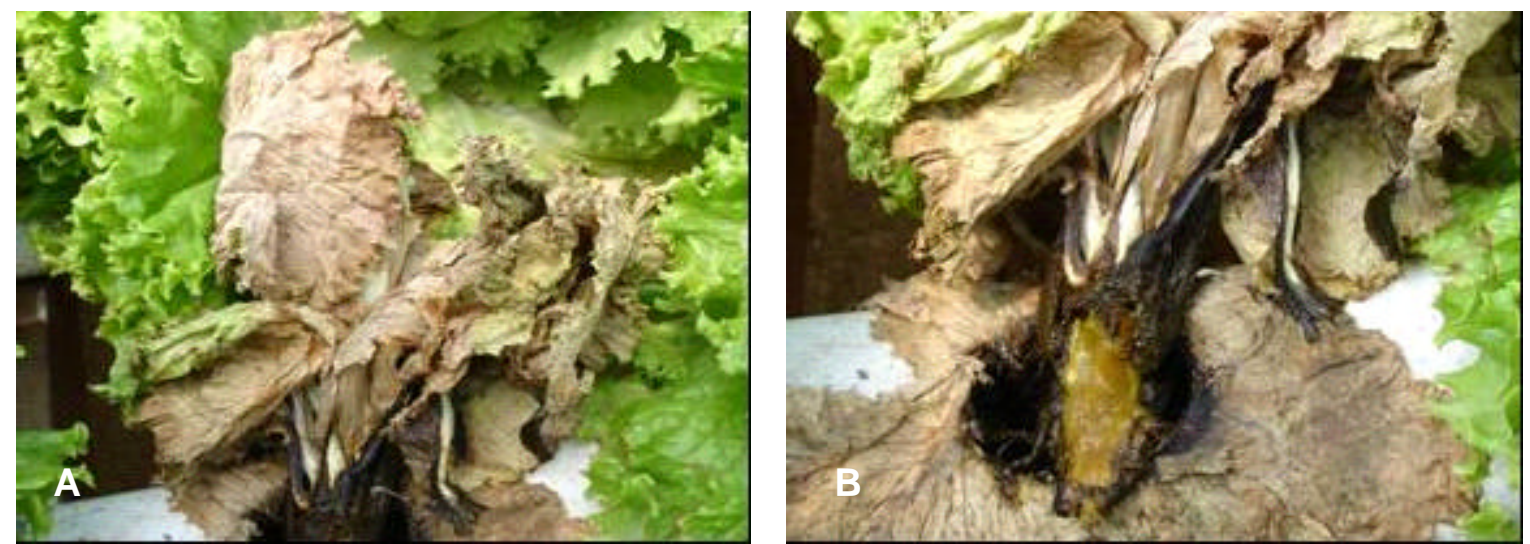

1. PODRIDÃO MOLE (Pectobacterium carotovorum) - (A) Sintomas em planta adulta (B) detalhe de podridão do colo na
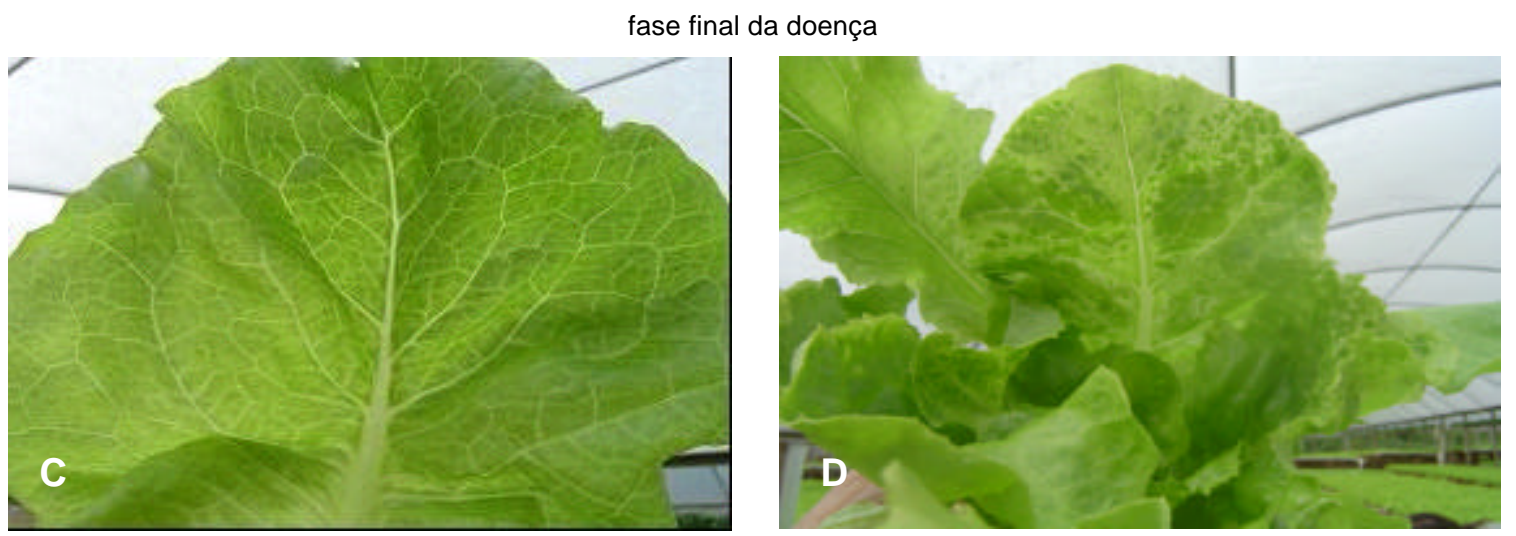

2. MOSAICO COMUM (Lettuce mosaic virus) - (C) Sintomas de clorose de nervuras na fase inicial da doença

(D) mosaico definido na fase final da doença
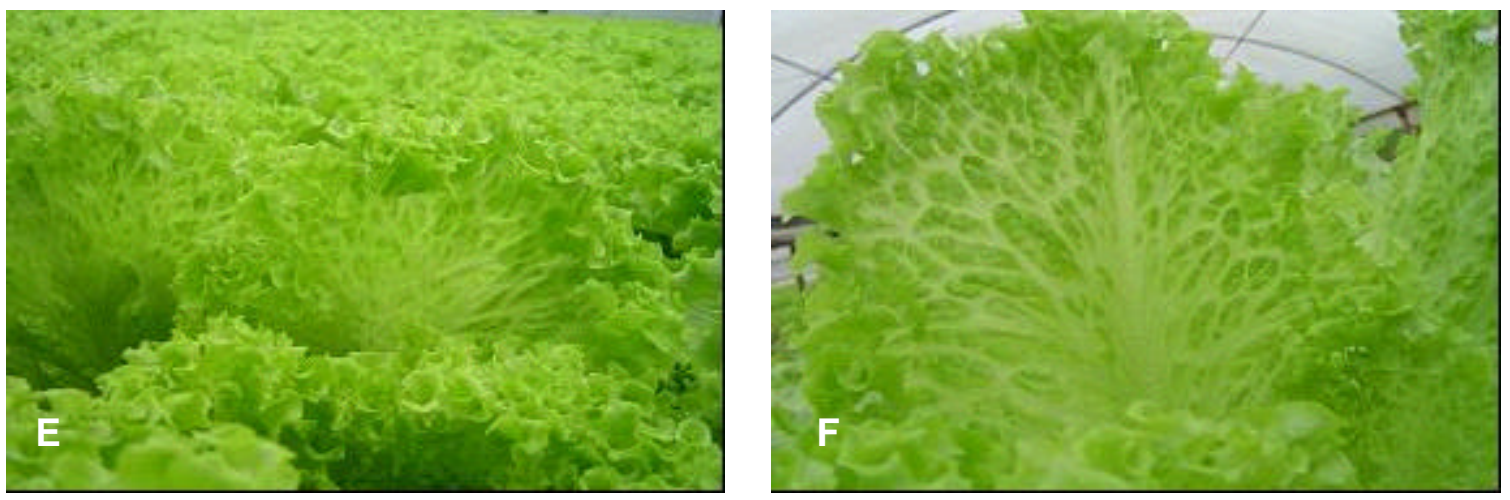

3. ESPESSAMENTO CLORÓTICO DAS NERVURAS (Lettuce big vein virus) - (E) Plantas infectadas

(F) detalhe da clorose de nervuras em folha

FIGURA 2 - Sintomas de doenças bacterianas e viróticas em alface hidropônica 
O míldio foi considerado, no presente trabalho, a doença mais importante da alface pela característica de incidir durante todas as fases da cultura (sementeira, berçário, fase final e colheita). Além disso, afeta severamente o desenvolvimento a produtividade e o aspecto comercial da planta. As lesões, causadas pela colonização do patógeno, iniciam na forma de pequenas pontuações cloróticas, tornam-se amareladas e, posteriormente, necróticas, podendo atingir em casos mais severos todo o limbo foliar. Na face abaxial se desenvolve uma eflorescência de coloração esbranquiçada constituída de hifas, esporangióforos e esporângios do fungo. (Figura 1.1).

Segundo COSTA et al. (1999) em regiões de clima temperado a primavera, final de verão e outono com temperaturas diurnas entre 12 e $20 \stackrel{\circ}{C}$ e noturnas entre 6 e $10^{\circ} \mathrm{C}$, são os períodos mais favoráveis ao desenvolvimento da doença com menor ocorrência durante o verão e inverno. Estas situações foram observadas nos cultivos de alface hidropônica nos municípios produtores no período vigente do trabalho, onde as maiores incidências do míldio foram detectadas nos períodos de primavera/outono e início de inverno.

O oídio foi considerado, neste levantamento, como uma doença de incidência comum no cultivo hidropônico, porém com menor severidade do que o míldio. Nas propriedades inspecionadas, ocorreu em todos os estádios da cultura e em todas as variedades cultivadas, com maior incidência na fase de acabamento. As bancadas apresentavam plantas infectadas de forma generalizada com os sintomas manifestando-se primeiramente nas folhas mais externas da planta. $\mathrm{Na}$ face adaxial das folhas surgem pontuações brancas constituídas de micélio, conidióforos e conídios que são as estruturas do patógeno (Figura 1.2) que evoluem para coloração cinza e atingem, geralmente, todo o limbo foliar provocando clorose e, posteriormente, necrose dos tecidos e ocasionando redução da área fotossintética. A disseminação deste patógeno ocorre pelo vento, e de acordo com COSTA et al. (1999), a germinação dos esporos e colonização das plantas ocorre em condições secas e quentes, fator este observado na relação de maior incidência da oídio na região metropolitana nos períodos de primavera e verão.

A queima da saia ou rizotoniose provoca podridão dos tecidos no colo das plantas e do sistema radicular. Trata-se de uma doença bastante severa, onde o amarelecimento das folhas e murcha da parte aérea, principalmente as folhas basais e medianas, são sintomas reflexos devido à invasão dos tecidos na região do colo e do sistema radicular. A infecção das plantas nas bancadas ocorreu com maior intensidade naquelas situadas no mesmo perfil (em linha). Com a evolução da doença, há tendência de a parte aérea desprender facilmente do sistema radicular (Figura 1.3). A queima da saia foi diagnosticada em todas as propriedades, sem distinção de variedades, manifestando-se principalmente em plantas mais desenvolvidas, próximas ao ponto de colheita. No levantamento efetuado foi constatada ocorrência também na fase de sementeira. Primavera, outono e inverno foram os períodos em que houve maior porcentagem de plantas afetadas e, onde, o fungo encontra condições predisponentes (temperaturas amenas e alta umidade) favoráveis ao seu desenvolvimento e disseminação, através de micélio e escleródios.

Entre as doenças fúngicas que atacam o sistema radicular, a podridão de esclerotínia (mofo branco) ocorreu em todas as fases da cultura provocando danos, inclusive, na fase de sementeira causando tombamento generalizado das mudas que se tornam inviáveis para transplante. Foi constatado em algumas propriedades que mudas, aparentemente sadias, são retiradas de sementeiras com ocorrência de $S$. sclerotiorum em reboleira, e transplantadas para os perfis (fase de viveiro) onde a doença evolui atuando como fonte de inóculo para outras plantas da bancada, o que explica as altas porcentagens de plantas adultas afetadas pelo mofo branco nessas propriedades.

Os sintomas iniciam pelo aparecimento de sintomas reflexos de murcha da parte aérea. $\mathrm{Na}$ região do colo observa-se necrose e rompimento dos tecidos, com presença de micélio branco e, na fase final da doença, o aparecimento de estruturas de resistência que são os escleródios (Figura 1.4). O maior número de plantas infectadas na bancada ocorre, geralmente, na mesma linha do perfil.

A podridão de esclerotínia é uma doença bastante comum em olericultura convencional e orgânica, afetando diversas outras espécies além da alface tais como repolho, rúcula feijão vagem, tomateiro e pepino tendo preferência por regiões ou épocas do ano com alta umidade relativa e temperatura amena (MARINGONI, 1997; PAVAN e KUROZAWA, 1997). VIEIRA et al. (2001), relatam que alta umidade e temperaturas amenas são condições extremamente favoráveis para o desenvolvimento da doença na cultura do feijoeiro convencional. No caso específico do presente trabalho, a doença foi constatada durante o ano todo, em todas as variedades utilizadas pelos produtores e a incidência foi maior nos períodos mais frescos (primavera/outono/inverno).

A podridão mole, causada pela bactéria Pectobacterium carotovorum, manifestou-se, predominantemente, em plantas em pleno desenvolvimento, que mostram, inicialmente, sintomas de murcha ocorrendo com maior freqüência na primavera e verão. Os tecidos da base das folhas das plantas afetadas tornam-se encharcados e de coloração verde-escura a negra, seguida de podridão (Figura 2.1), muitas vezes, exalando odor fétido. Tecidos debilitados fisiologicamente devido a desbalanços nutricionais são mais propensos ao ataque. Ferimentos naturais, provocados pelo crescimento das raízes, ou aqueles produzidos por insetos, práticas culturais ou por insetos também facilitam a penetração da bactéria (LOPES e QUEZADO-SOARES, 1997; GOMES e RODRIGUES, 2001.), situação comum no sistema de cultivo hidropônico. 
O mosaico da alface (LMV) foi a menos prevalente de todas as doenças diagnosticadas nos levantamentos realizados e os períodos de maior ocorrência foram o outono e inverno. Os sintomas da virose em plantas do grupo crespo são menos visíveis tornando praticamente impossível a diagnose a olho nú. Nas variedades de alface lisas do grupo manteiga os sintomas são mais evidentes e a infecção pelo vírus induz sintomas de mosaico típico constituído de áreas verde-claras e verde-escuras no limbo podendo apresentar ou não má formação foliar (Figura 2.2). O vírus do mosaico da alface é um dos mais importantes em áreas de produção comercial desta hortaliça possivelmente devido ao uso de sementes infectadas e rápida disseminação por inúmeras espécies de afídios. DINANT e LOT (1992) relatam que o LMV apresenta uma ampla gama de hospedeiros, infetando 121 espécies vegetais pertencentes a 60 gêneros e 17 famílias botânicas.

Os dados obtidos nos levantamentos realizados mostraram que o espessamento clorótico das nervuras é a principal doença virótica na cultura da alface hidropônica. Plantas afetadas pelo complexo viral mostram sintomas de clorose ao longo das nervuras das folhas, hábito de crescimento irregular e ausência de formação de cabeça (Figura 2.3).

Nas propriedades inspecionadas, a virose ocorreu de forma intensa principalmente nos períodos mais frescos do ano (outono e inverno) afetando $100 \%$ das plantas em algumas bancadas. Os testes realizados mostraram que em plantas com sintomas de espessamento clorótico ocorrem dois vírus distintos: o vírus Mirafiori da alface (MiLV) e o vírus associado do espessamento (LBVV).

Os dois vírus são transmitidos pelo fungo Olpidium brassicae Woronin (LOT et al., 2002) e, segundo ROGGERO et al. (2000), o MiLV é o responsável pelos sintomas de espessamento clorótico e o LBVV causa somente infecção latente. Estudos realizados no Estado de São Paulo por COLLARICCIO et al. (2005) confirmaram esses resultados.

Testes de transmissão e observações realizadas no presente trabalho, a partir de amostras coletadas no verão e primavera, mostraram que além de os sintomas se tornarem menos evidentes, quase latentes, nesses meses mais quentes, a porcentagem de plantas afetadas é menor, geralmente em torno de 30\%. Essa redução na incidência, provavelmente, está relacionada com temperaturas mais altas que ocorrem nesse período interferindo de alguma forma na capacidade de sobrevivência dos vírus envolvidos na síndrome do espessamento clorótico e/ou do fungo vetor desses vírus.

As observações realizadas durante o período abrangido pela pesquisa indicam que há necessidade de estudos aprofundados em relação à epidemiologia e controle dessas doenças no sistema hidropônico. A importância de determinadas doenças, como por exemplo, a podridão mole, o mofo branco, o espessamento clorótico e a queima da saia, quando comparadas com a ocorrência em plantios convencional e orgânico, assumem uma importância significativa tendo em vista a rápida disseminação dessas, via solução nutritiva. Outra variável importante está relacionada com as instalações do sistema hidropônico, principalmente os reservatórios de solução nutritiva que podem se tornar excelente fonte de propágulos para todo o sistema.

A pesquisa realizada demonstrou, também, que há necessidade de assistência técnica aos produtores, tendo em vista a falta de conhecimento em relação a doenças. Anomalias causadas por agentes não patogênicos tais como danos por insetos, ácaros e nutrição mineral são comumente confundidas com doenças. Por outro lado, o inverso também ocorre. Sintomas provocados pelo complexo viral do espessamento clorótico das nervuras foram confundidos, pela grande maioria dos produtores entrevistados, como anomalias de nutrição.

A identificação das doenças realizadas neste trabalho e as épocas de maior ocorrência, fornecem dados seguros para a realização de futuras pesquisas sobre a epidemiologia e medidas de controle mais adequadas para o sistema hidropônico.

\section{CONCLUSÕES}

1) O levantamento realizado, em 10 propriedades de cultivo hidropônico, localizadas na região metropolitana de Curitiba, mostrou que ocorrem na cultura da alface sete doenças sendo quatro fúngicas (míldio, mofo branco, oídio, rizotoniose) duas viróticas (complexo do espessamento clorótico das nervuras, mosaico da alface) e uma bacteriana (podridão mole).

2) O míldio, o vírus do mosaico da alface, o complexo viral do espessamento clorótico das nervuras, queima da saia e podridão de esclerotínia foram mais prevalentes no outono e inverno. Oídio e podridão mole prevaleceram na primavera e verão.

\section{REFERÊNCIAS}

1. ALMADA, J.B.C. Avaliação de métodos de inoculação e controle químico e alternativo de Pseudoperonospora cubensis (Bert. \& Curt.) agente causal do míldio do pepino. Curitiba: 1998. $61 \mathrm{f}$. Dissertação (Mestrado em Ciência) - Curso de Pós Graduação em Agronomia-Produção Vegetal - Setor de Ciências Agrárias, Universidade Federal do Paraná.

2. ARAUJO, J.A.C. Recentes avanços da pesquisa agronômica na plasticultura brasileira. In: ARAUJO, J. A.C. ; CASTELANE, P. D. (Eds.). Plasticultura. Jaboticabal. FUNEP, 1991, p. 41-52.

3. COLARICCIO, A.; CHAVES, A.L.R.; EIRAS, M.; CHAGAS, C.M.; ROGGERO, P. Detection of Varicosavirus and Ophiovirus in lettuce associated with lettuce big-vein symptoms in Brazil. Fitopatologia Brasileira, v. 30, n. 4, p. 444-447, 2005 
4. COSTA, I. D. da; SANTOS, O.; SCHMIDT, D.; NOGUEIRA, H.; LONDERO, F.; PILAU, F.; BONNECARRERE, R.; MARIANI, O.; ROCHA, E. da; MICHELON, S. Cultivo hidropônico de alface - IV recomendações para o controle de doenças fúngicas. Santa Maria: UFSM, 1999. 5 p. (Informe Técnico, 7).

5. DINANT, S.; LOT, H. Lettuce mosaic virus. Plant Pathology, v. 41, p. 528-542, 1992.

6. GOMES, A. M. A.; RODRIGUES, V. J. L. B. Diagnose e manejo de doenças em cultivos hidropônicos. In: Proteção de plantas na agricultura sustentável. Recife: UFRPE, 2001. p. 225-242.

7. LOPES, C.A.; QUEZADO-SOARES, A.M. Doenças bacterianas das hortaliças: diagnose e controle. Brasília: EMBRAPA-CNPH, 1997. $70 \mathrm{p}$.

8. LOT, H.; CAMPBELL, R.N.; SOUCHE, S.; MILNE, R.G.; ROGGERO, P. Transmission by Olpidium brassicae of Mirafiori lettuce virus and Lettuce big-vein virus, and their roles in lettuce big-vein etiology. Phytopathology, v. 92, p. 288293, 2002.

9. KAMIKOGA, A.T.M. Método da folha destacada para avaliar resistência da soja ao oídio. Curitiba, 2001. 86 f. Tese (Doutorado em Agronomia-Produção Vegetal) - Setor de Ciências Agrárias, Universidade Federal do Paraná.

10. LIMA NETO, V. da C., LIMA, M.L.R.Z. da C.; TOMAZ, R. Coleta e remessa de amostras para diagnose de doenças de plantas. Curitiba: Imprensa Universitária da UFPR, 2003, 36 p.

11. MORDUE, J.E.M. Thanatephorus cucumeris. Cambridge: CAB, 1974. (CMI descriptions of pathogenic fungi and bacteria, 406).

12. MORDUE, J.E.M.; HOLLIDAY, P. Sclerotinia sclerotiorum. Cambridge: CAB, 1976. (CMI descriptions of pathogenic fungi and bacteria, 513).

13. MORGAN, W.M. Bremia lactucae. Cambridge. CAB, 1981. (CMI descriptions of pathogenic fungi and bacteria, 682).

14. PAVAN, M.A.; KUROZAWA, C. Doenças da alface. In: KIMATI, H.; AMORIN, L.; BERGAMIN FILHO, A; CAMARGO, L.E.A.; REZENDE, J.A.M. Manual de fitopatologia: doenças das plantas cultivadas. v. 2. São Paulo: Agronômica Ceres, 1997. p.18-25.

15. RODRIGUES NETO, J.; ROMEIRO, R. da S. Diagnose de enfermidades de plantas incitadas por bactérias. Viçosa: UFV, 2001. 67 p. (Cadernos didáticos).

16. ROGGERO, P., CIUFFO, VAIRA, A.M., ACCOTTO, G.P., MASENGA, V.; MILNE, R.G. An Ophiovirus isolated from lettuce with big-vein symptoms. Archives of Virology, v. 145, n. 12, p. 2629-2642, 2000.

17. ROMEIRO, R.S. Isolamento de bactérias fitopatogênicas a partir de órgãos vegetais infectados, pelo método padrão. In: Métodos em bacteriologia de plantas. Viçosa; Universidade Federal de Viçosa, 1998.

18. SCHAAD, N.W. Laboratory guide for identification of plant pathogenic bacteria. St. Paul: Minnesota. 1980.

19. SANTOS, H.S. Comportamento fisiológico de hortaliças em ambiente protegido. In: ENCONTRO DE HORTALIÇAS DA REGIÃO SUL, 9., ENCONTRO DE PLASTICULTURA DA REGIÃO SUL, 6., Maringá-PR, 1994. Anais. Maringá, 1994. p.22-24.

20. TAKATSU, A., MELLO, S.C.M.; GARCIA, E.S.O.B. Fruto de pimentão como meio parcialmente seletivo para isolamento de Erwinia carotovora. Fitopatologia Brasileira, v. 6, p. 551, 1981.

21. TOMLINSON, J.A. Lettuce mosaic virus. Cambridge: CAB, 1970. (CMI/AAB Description of plant viruses, 9).

22. VIDA, J.B.; ZAMBOLIN, L.; COSTA, H.; VALE, F.X.R. Manejo de doenças em cultivos protegidos. In: ZAMBOLIN, L. (Ed.). Manejo integrado, fitossanidade, cultivo protegido, pivô central e plantio direto. Viçosa: Suprema Gráfica e Editora, 2001. p. 55-118.

23. VIEIRA, R.F.; PAULA JR, T.J. de; PERES, A.P.; MACHADO, J. da C. Fungicidas aplicados via água de irrigação no controle do mofo branco no feijoeiro e incidência do patógeno na semente. Fitopatologia Brasileira, v. 26. n. 4, p. 770-773, 2001. 
